УДК 547.913

\title{
Obtaining of Organomineral Fertilizers on the Basis of Wood Bark (Review)
}

\author{
Evgeniya V. Veprikova, Svetlana A. Kuznetsova, \\ Nikolai V. Chesnokov and Boris N. Kuznetsov* \\ Institute of Chemistry and Chemical Technology SB RAS \\ FRC "Krasnoyarsk Science Center SB RAS" \\ 50/24 Akademgorodok, Krasnoyarsk, 660036, Russia
}

Received 11.08.2016, received in revised form 29.10.2016, accepted 16.11.2016

Analytical review of the literature devoted to obtaining and to study of properties of organic and organomineral fertilizers based on a wood bark was performed. Biotechnological methods of wood bark processing under aerobic and anaerobic conditions were considered. Methods of obtaining of new fertilizers on the basis at birch bark - biocomposite organomineral fertilizers with the prolonged action were described. The promising directions were defined for advanced studies on the field of fertilizers obtaining from wood bark.

Keywords: fertilizer, organic, organomineral, wood bark, prolonged action.

DOI: $10.17516 / 1998-2836-2016-9-4-414-429$.

(C) Siberian Federal University. All rights reserved

* Corresponding author E-mail address: inm@icct.ru 


\title{
Получение органоминеральных удобрений \\ на основе древесной коры (обзор)
}

\author{
Е.В. Веприкова, С.А. Кузнецова, \\ Н.В. Чесноков, Б.Н. Кузнецов \\ Институт химии и химической технологии СО РАН \\ ФИЦ «Красноярский научный иентр СО РАН» \\ Россия, 660036, Красноярск, Академгородок, 50/24
}

Проведен аналитический обзор литературы, посвященной получению и изучению свойств органических и органоминеральных удобренийна основе отходов древесной коры. Рассмотрены биотехнологические методы переработки коры в аэробных и анаэробных условиях, а также методы получения удобрений из исходной и проэкстрагированной коры. Описаны методы получения и свойства удобрений на основе коры березы - биокомпозитных органоминеральных удобрений пролонгированного действия. Определены перспективные направления исследовательских работ в области получения удобрений из древесной коры.

Ключевые слова: удобрение, органическое, органоминеральное, древесная кора, пролонгированное действие.

Задача рационального использования древесных отходов актуальна для большинства стран, обладающих развитой лесоперерабатывающей промышленностью. В процессе получения древесины на перерабатывающих предприятиях накапливаются многотоннажные отходы, среди которых на долю коры приходится в среднем до $10 \%$ от общего объема. Основная практика утилизации отходов коры - вывоз в отвалы или сжигание, что создает негативную техногенную нагрузку на окружающую среду. При этом потенциал коры различных пород деревьев как уникального, практически неисчерпаемого сырья для получения различных востребованных химических веществ, сорбентов и других материалов, хорошо известен [1-3]

Отходы древесной коры являются важным источником гумусообразования. Кора содержит разнообразные органические вещества, в том числе и легкоразлагаемые, и минеральные соединения, важные для питания растений. Это позволяет возвращать в круговорот природы изъятую у нее органическую часть, необходимую для нормального функционирования почвенно-биотического комплекса $[4,5]$. Поэтому наиболее рационально использовать отходы коры для производства органических и органоминеральных удобрений. Такое направление приобретает особую перспективность в связи с тем, что интенсивное земледелие приводит к быстрому снижению плодородия почв, что вызвано минерализацией гумуса. Несмотря на огромный накопленный опыт $[1,3,6]$, получение органических и органоминеральных удобрений на основе древесной коры остается актуальной задачей.

В данной статье проведен анализ публикаций последних 10-12 лет по способам получения и свойствам удобрений на основе древесной коры.

$$
-415 \text { - }
$$




\section{Методы переработки отходов коры в удобрения}

В литературе, опубликованной в России и за рубежом, предлагаются различные способы получения органических и органоминеральных удобрений из древесной коры. Эти способы можно разделить на две группы: способы получения удобрений в результате биоразложения коры в аэробных и анаэробных условиях, а также способы получения, в которых применяется исходная или проэкстрагированная кора.

\section{Биотехнологические методы переработки}

К биотехнологическим методам конверсии отходов древесной коры в органоминеральные удобрения относятся: компостирование, вермикомпостирование, биоразложение под действием ферментов и бактерий, биоконверсия органического вещества коры под действием грибов.

Наиболее простым и малозатратным способом утилизации древесной коры является ее компостирование [7, 8]. Интерес к получению таких компостов обусловлен разнообразием, доступностью и дешевизной сырья.

Кроме того, внесение компостов позитивно влияет на физико-химические свойства почвы за счет разуплотнения ее верхнего слоя и повышения общей пористости. Это приводит к значительному улучшению аэрации почвы, повышению ее влажности и водовместимости. Внесение компостов сопровождается увеличением в почве доли ценных агрегатов и их водостойкости, повышением содержания гумуса и его подвижных форм. Важно отметить, что компосты благоприятствуют биологической активности почвы, что влияет на ее плодородие [9-12]. Внесение компоста оказывает сильное влияние на состояние основных макроэлементов питания растений, которые могут абсорбироваться на частицах почвы или образовывать комплексы с органическими веществами. В результате изменяется характер их накопления, водостойкость и биодоступность [13]. При изучении свойств компоста из сосновой коры было установлено его ингибирующее действие на фитофтору. По эффективности этого действия компост сравним с химическими и биологическими фунгицидами, что позволяет сократить долю дорогостоящих препаратов при выращивании растений [14].

Основное внимание при разработке способов получения и усовершенствовании составов компостов из древесной коры уделялось применению различных минеральных и органических добавок. По-прежнему актуальны добавки традиционных удобрений, вермикулита и природных алюмосиликатов $[15,16]$. Минеральные удобрения позволяют сбалансировать питательные макроэлементы в компосте. Внесение вермикулита и алюмосиликатов приводит к увеличению пористости и влагоемкости компоста, что ускоряет процесс биоразложения коры. Применение алюмосиликатов, благодаря их специфическому строению и сорбционной активности, придает компосту эффект пролонгированного действия [16].

Включение в состав смеси для компостирования добавок гидрофильных полимеров и их соединений с металлами способствует улучшению водного баланса и аэрации компоста в процессе его биоконверсии. За счет таких добавок получаемый компост характеризуется высокой влагоемкостью и хорошей водоудерживающей способностью [17].

Актуальное направление - биопереработка древесной коры совместно с отходами различных производств (табл. 1). Осадки сточных вод (ОСB) разной природы - ценные источ- 
Таблица 1. Получение органоминеральных удобрений из древесной коры и отходов различных производств

\begin{tabular}{|c|c|c|c|c|}
\hline Древесные отходы & Добавка & $\begin{array}{c}\text { Процесс } \\
\text { биопереработки; } \\
\text { продолжительность }\end{array}$ & $\begin{array}{c}\text { Свойства } \\
\text { удобрения }\end{array}$ & Ссылка \\
\hline Короотвалы ЦБК & $\begin{array}{l}\text { Осадки сточных } \\
\text { вод (ОСВ) очистных } \\
\text { сооружений }\end{array}$ & \begin{tabular}{|l} 
Компостирование, \\
активированное \\
аэрацией атмосферным \\
воздухом; 6 мес.
\end{tabular} & $\begin{array}{l}\mathrm{N}_{\text {общ }} 2,74 \%, \\
\text { содержание } \\
\text { гумуса-1,78 \% }\end{array}$ & [19] \\
\hline $\begin{array}{l}\text { Смесь древесных } \\
\text { опилок и коры } \\
\text { твердых пород } \\
\text { древесины }\end{array}$ & $\begin{array}{l}\text { ОСВ и отходы } \\
\text { жизнедеятельности } \\
\text { птицы }\end{array}$ & $\begin{array}{l}\text { Компостирование; } \\
60-120 \text { дней }\end{array}$ & $\mathrm{C} / \mathrm{N} 17,8-19,0$ & {$[20]$} \\
\hline $\begin{array}{l}\text { Кора породы } \\
\text { Sesame }\end{array}$ & $\begin{array}{l}\text { ОСВ производства } \\
\text { оливкового масла }\end{array}$ & $\begin{array}{l}\text { Компостирование; } \\
\text { не менее } 7 \text { мес. }\end{array}$ & $\begin{array}{l}\text { C/N 18,75, } \\
\text { содержание } \\
\text { гуминовых } \\
\text { веществ 4,5 \% } \\
\end{array}$ & {$[21]$} \\
\hline $\begin{array}{l}\text { Смесь коры } \\
\text { твердых и мягких } \\
\text { пород древесины } \\
\text { (или смесь } \\
\text { древесных опилок) }\end{array}$ & $\begin{array}{l}\text { Отходы пивной } \\
\text { промышленности }\end{array}$ & $\begin{array}{l}\text { Компостирование } \\
\text { при } 60^{\circ} \mathrm{C} ; 8 \text { мес. }\end{array}$ & $\mathrm{C} / \mathrm{N} 8,0$ & [22] \\
\hline $\begin{array}{l}\text { Компост из } \\
\text { древесной коры и } \\
\text { опилок }\end{array}$ & $\begin{array}{l}\text { Отходы пивной } \\
\text { промышленности и } \\
\text { побочные продукты } \\
\text { (солодовое сусло, } \\
\text { сладкая сыворотка) }\end{array}$ & $\begin{array}{l}\text { Анаэробная } \\
\text { ферментация; 120-140 } \\
\text { дней }\end{array}$ & $\begin{array}{l}\mathrm{C} / \mathrm{N} \text { не менее } \\
10,0-15,0\end{array}$ & {$[23]$} \\
\hline $\begin{array}{l}\text { Смесь древесной } \\
\text { коры и } \\
\text { растительных } \\
\text { отходов }\end{array}$ & $\begin{array}{l}\text { Отходы кожевенного } \\
\text { производства и } \\
\text { производства мяса }\end{array}$ & $\begin{array}{l}\text { Ферментация; не менее } \\
2-3 \text { мес. }\end{array}$ & $\mathrm{C} / \mathrm{N}$ не менее 10,0 & [24] \\
\hline
\end{tabular}

ники фосфора, цинка, магния и других биогенных элементов [18-20]. Внесение в почву компостов, в которых содержание $\mathrm{Mg}, \mathrm{Mn}, \mathrm{Zn}, \mathrm{Co}$ и др. не превышает уровня их ПДК, способно обеспечить бездефицитный баланс макро- и микроэлементов в севообороте в течение длительного времени.

Осадки сточных вод наряду с веществами-нутриентами могут содержать и токсичные компоненты, например фенольные соединения. В работе [21] продемонстрирован эффективный способ снижения фитотоксичности ОСВ производства оливкового масла - компостирование в присутствии коры породы Sesame. Исследования кинетики показали, что количество водорастворимого фенола в течение 7 месяцев компостирования сокращаются на 72 \%. Через 7 месяцев растворимых фенольных соединений в компосте не обнаруживается. При этом достигнутое соотношение $\mathrm{C} / \mathrm{N}$ и содержание гуминовых веществ позволяет считать компост приемлемым для сельскохозяйственного применения.

Совместная биопереработка отходов пивоварения, производства кожи и мяса с растительными отходами, в том числе древесной корой, позволяет получать органические удобрения с широким набором биогенных питательных веществ (аминокислот, микроэлементов), характеризующихся высокой доступностью и усвояемостью [22-24]. 
Обзор литературы установил, что в последние 10-12 лет вермикомпостированию древесной коры и ее биоконверсии с помощью грибов посвящены работы $[25,26]$. Незначительное внимание к этим методам переработки древесных отходов обусловлено, очевидно, необходимостью подбора видов червей и грибов, обладающих оптимальной продуктивностью для конверсии используемого сырья. Кроме того, для получения качественных удобрений требуется соблюдение определенных условий и питательной среды. Следует отметить, что такие методы имеют и свои преимущества. Например, вермикомпосты проявляют большую эффективность по сравнению с обычными компостами, поскольку содержат питательные вещества в более доступных для растений формах. Положительное влияние вермикомпостов на рост растений может быть связано со способностью червей производить определенные биоактивные метаболиты и витамины разных групп [8, 27].

Биоконверсия луба коры березы в присутствии грибов рода Trichoderma (штамм MT-97) в условиях различного азотного питания (аммонийного или нитратного, 3 \% от массы субстрата) позволяет получать биопрепарат типа «Триходермин», который используется в борьбе с болезнями растений, и гумусовое удобрение. Биопрепарат был получен в процессе культивирования грибов в условиях аммонийного питания. При этом выход спор грибов возрастает в 42 раза уже после 5 сут проведения процесса. Биодеструкция луба в присутствии нитратного азота сопровождается его быстрой гумификацией - массовая доля гуминовых веществ достигает 17,9 \% уже на 4-е сут культивирования. Это дает возможность считать такой подход к переработке отходов березовой коры более перспективным по сравнению с компостированием. Получаемое гумусовое удобрение обогащено спорами грибов, способных подавлять развитие фитопатогенов [26].

Основной недостаток биотехнологических приемов переработки отходов коры в удобрения - это значительная длительность. На динамику процессов биодеградации, что особенно характерно для компостирования, сильное влияние оказывает видовая принадлежность коры (табл. 2). Авторами работ [30,31] показано, что удобрительные композиции с осиновой корой разлагаются быстрее, чем на основе коры хвойных пород. В результате возникает необходимость сортировки отходов древесной коры перед закладкой компостных буртов [6].

Таблица 2. Характеристики динамики разложения коры разных пород деревьев (по данным работ [2831])

\begin{tabular}{|c|c|c|c|c|c|c|c|}
\hline \multirow{3}{*}{ Вид коры } & \multicolumn{6}{|c|}{ Период разложения, сут } & \multirow{3}{*}{$\begin{array}{c}\mathrm{C}_{\Gamma \mathrm{KK}}: \mathrm{C}_{Ф \mathrm{\Phi К}} \\
\text { (3а } 360 \mathrm{cyT} \text { ) }\end{array}$} \\
\hline & \multicolumn{2}{|c|}{$0-90$} & \multicolumn{2}{|c|}{$90-180$} & \multicolumn{2}{|c|}{$0-360$} & \\
\hline & $\mathrm{C}, \%$ & $\mathrm{k}$ & $\mathrm{C}, \%$ & $\mathrm{k}$ & $\mathrm{C}, \%$ & $\mathrm{k}$ & \\
\hline Кора лиственницы & 32,6 & 0,022 & 22,8 & 0,016 & 100 & 0,076 & 0,81 \\
\hline Кора ели & 37,1 & 0,034 & 24,1 & 0,022 & 100 & 0,100 & 1,33 \\
\hline Кора сосны & 30,0 & 0,028 & 28,8 & 0,028 & 100 & 0,110 & 0,83 \\
\hline Кора осины & 27,5 & 0,048 & 27,8 & 0,051 & 100 & 0,23 & 1,55 \\
\hline
\end{tabular}

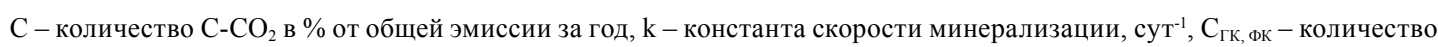
углерода гуминовых и фульвокислот. 


\section{Получение удобрений из исходной и проэкстрагированной коры}

На основе древесной коры можно получать различные органоминеральные удобрения, не применяя методов ее биопереработки. Например, из смеси древесных коры и золы с добавками различных питательных макро- и микроэлементов предложено получать удобрения в виде пеллет [32]. Композиции для получения гранулированных удобрений помимо отходов коры могут содержать разнообразные компоненты, например ферментированные древесные опилки, остатки водяных растений, отходы жизнедеятельности животных, минеральные добавки (глина и др.) [33]. Доля коры в композиции может варьироваться от 10 до 30 \%.

Известно, что древесная кора содержит достаточно большое количество водорастворимых полифенольных соединений, отрицательно влияющих на рост растений. Установлено, что даже малые количества коричной, кумаровой, салициловой и бензойной кислот ингибируют рост растений, а многие фенолкарбоновые кислоты токсично влияют на прорастание семян [34]. Подвижные формы фенольных соединений коры оказывают негативное влияние на почвенную микрофлору [35]. Поэтому целесообразно проводить предварительное удаление полифенольных соединений из коры. Кроме того, предварительная гидрообработка коры позволяет удалять из нее споры грибов, бактерий и других остатков, вредных для роста растений [36].

В этой связи перспективным сырьем для получения удобрений являются остатки экстрагирования древесной коры. Обработка различными органическими растворителями обеспечивает существенное снижение фитотоксичных соединений. Остатки экстракции характеризуются высокой пористостью и влагоемкостью, что обеспечивает их эффективность при использовании в качестве структурирующих добавок. В результате биоразложения таких материалов в почве увеличивается доля гумусных веществ [37, 38]. Применение для экстрагирования веществ с биогенными элементами, например спиртовой раствор $\mathrm{KOH}$ для обработки луба коры березы, дает возможность применять пористый остаток в качестве калийного удобрения. Однако при проведении экстракции в предложенных условиях (под действием сверхвысокочастотного поля) из луба удаляется значительное количество биогенных ростостимулирующих веществ [38].

В литературе описано получение азотсодержащего удобрения из коры сосны обыкновенной в результате ее обработки водным раствором аммиака в присутствии кислорода под давлением (окислительный аммонолиз) в течение 3 ч. Было установлено, что такая обработка приводит к удалению части органических и минеральных веществ коры. В результате масса лигнина в азотсодержащих продуктах, полученных из корки и луба коры сосны, увеличивается на 13,5 и $19,5 \%$ от исходного количества, а содержание азота - в 8,6 и 4,2 раза соответственно. Кроме того, получаемые удобрения содержат различные неорганические макро- и микроэлементы (табл. 3) [39].

Вегетационные тесты показали, что получаемые органические удобрения из коры сосны оказывают позитивное влияние на прирост биомассы овса, причем эффективность этих удобрений превосходит традиционное азотсодержащее минеральное удобрение [39].

Пористая структура и наличие активных функциональных групп разной природы делает остатки химической переработки коры ценным материалом для создания органоминеральных удобрений пролонгированного действия. Следует отметить, что создание удобрений пролон- 
Таблица 3. Состав азотсодержащих удобрений из компонентов коры сосны

\begin{tabular}{|c|c|c|}
\hline Компонент, \% & Удобрение из корки & Удобрение из луба \\
\hline Лигнин & 28,6 & 10,6 \\
\hline Целлюлоза & 24,1 & 42,8 \\
\hline Азот & 2,4 & 1,8 \\
\hline Калий* & 21,1 & 4,6 \\
\hline Магний* & 62,7 & 52,5 \\
\hline Марганец* & 57,9 & 29,2 \\
\hline Цинк* & 56,1 & 34,5 \\
\hline Медь* $^{*}$ & 26,1 \\
\hline Бор* & 29,2 & 29,1 \\
\hline
\end{tabular}

* \% от содержания в исходном сырье.

гированного действия - актуальное, быстро развивающееся направление. Применение таких удобрений позволяет решать комплекс задач: повысить эффективность использования традиционных водорастворимых удобрений за счет снижения их вымывания грунтовыми водами; снизить уровень загрязнения грунтовых и поверхностных вод в районах земледелия; сократить расходы на внесение удобрений и др. [40].

Пролонгированное действие удобрений может быть обеспечено использованием различных оболочек - из стекла, карбамидоформальдегидной смолы и др. Другая возможность обеспечить эффект пролонгированного действия - применение пористых подложек для нанесения активных элементов в качестве носителя питательных элементов, материала с сорбционными или ионообменными свойствами. В качестве таких подложек предложено применять природные цеолиты, глаукониты, диатомиты и другие неорганические материалы подобной природы, которые за счет своего строения и сорбционной активности способны удерживать нанесенные активные компоненты [41, 42].

Однако применение отходов древесной коры для получения пористых подложек более предпочтительно, так как в результате их биодеградации после выделения нанесенных питательных компонентов почва дополнительно обогащается комплексом органических и минеральных веществ. Кроме того, как было установлено при исследовании свойств коры сосны Douglas Fir, для органоминерального комплекса коры характерна меньшая микробиологическая активность и, соответственно, меньшая иммобилизация азота по сравнению с опилками $[43,44]$. Важно отметить, что кора является источником водорастворимых биогенных микроэлементов (бора, марганца, меди, железа и др.), доступных для растений в течение длительного времени - не менее 2 месяцев [45]. Кроме того, питательные катионы из удобрений и почвенных растворов могут закрепляться на поверхности частиц коры в результате ионного обмена и расходоваться для питания растений в течение длительного времени [36]. Также отмечено, что применение коры способствует снижению высоких доз нитратов, угнетающих рост растений [46].

В работах [47-49] показана возможность получения и описаны свойства биокомпозитных удобрений на основе коры березы, содержащих в качестве активных компонентов азот, калий и 


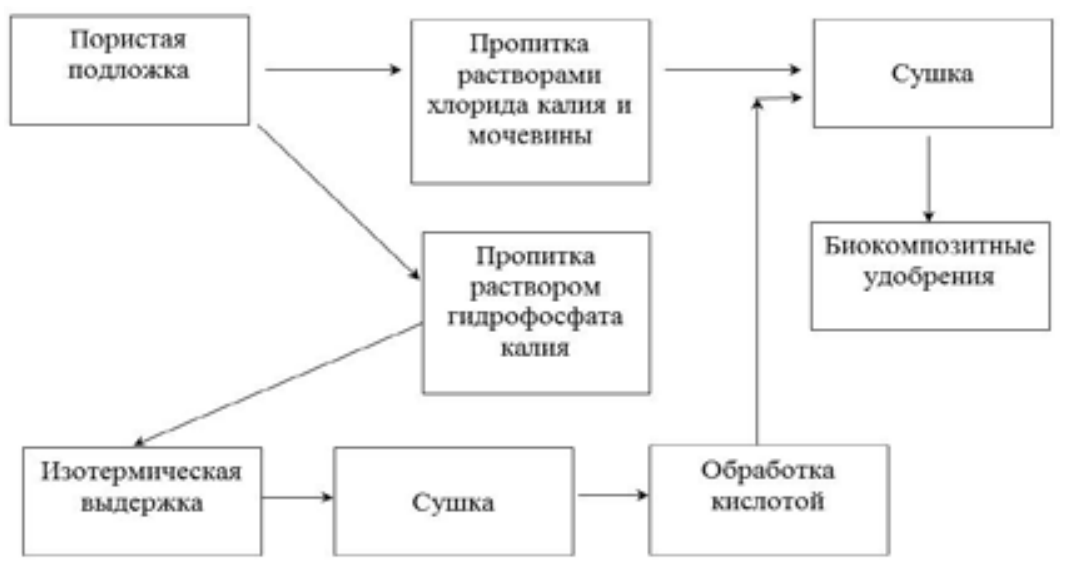

Рис. 1. Схема получения биокомпозитных удобрений на основе пористых подложек из коры березы

фосфора, и характеризующихся замедленным вымыванием этих компонентов водой в течение длительного времени. Схема получения биокомпозитных удобрений приведена на рис. 1.

Эффект пролонгированного действия достигается за счет пропитки растворами удобрений (мочевины, хлорида и гидрофосфата калия) пористых подложек из луба и коры березы, которые были получены обработкой исходного сырья 1,5\%-ным водным раствором $\mathrm{NaOH}$. В результате щелочной обработки происходит удаление полифенольных веществ и развитие пористой структуры материала. При этом в подложках сохраняется достаточное количество лигнина, разложение которого будет способствовать увеличению содержания в почве гумуса [50]. Также на поверхности подложек из коры и луба березы зафиксировано наличие парамагнитных феноксирадикалов, ионов $\mathrm{Fe}^{3+}$ и $\mathrm{Mn}^{2+}$, ферромагнитных наночастиц $\mathrm{Fe}_{3} \mathrm{O}_{4}$, которые могут принимать участие в закреплении наносимых активных компонентов в подложках [47].

Пропитку подложек растворами удобрений проводили исходя из их влагоемкости, когда объем раствора соответствует объему пор подложки. Этот способ традиционно используется при получении нанесенных катализаторов. Наряду с простотой выполнения способ позволяет наносить на подложку точно рассчитанное количество активного компонента. После высушивания мелкодисперсные частицы нанесенных солей локализуются в порах и на поверхности получаемых органических удобрений. Дозированное выделение питательных элементов вследствие затрудненной диффузии из пор подложек увеличивает продолжительность действия биокомпозитных удобрений.

Вегетационные эксперименты по выращиванию кресс-салата, результаты которых приведены в работе [47], выявили ростостимулирующее действие азотсодержащих биокомпозитных удобрений на основе подложек из коры и луба березы (рис. 2, табл. 4). Наиболее заметное влияние на рост кресс-салата проявляет биокомпозитное удобрение из коры березы. При добавлении этого удобрения в почву наблюдается 100\%-я всхожесть семян, увеличение средней длины растений на 24 \% и увеличение сухой фитомассы на 89 \% относительно контроля. В серии опытов с добавлением в почву мочевины наблюдается ингибирование роста кресс-салата изза превышенной концентрации азота, а в сериях с добавлением биокомпозитных удобрений улучшение показателей роста (табл. 4).

$$
-421-
$$




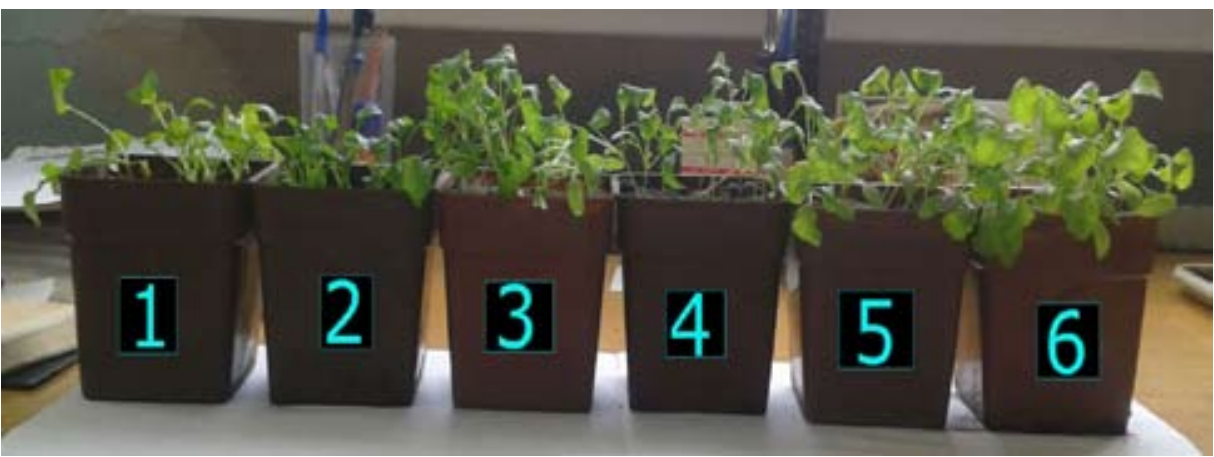

Рис. 2. Растения кресс-салата на 22-й день после посева семян: 1) почва - контроль; 2) почва + мочевина; 3) почва+удобрение на основе луба; 4) почва+ПП из луба; 5) почва+удобрение на основе коры березы; 6) почва+ПП из коры березы

Таблица 4. Влияние пористых подложек и биокомпозитных удобрений на основе коры и луба березы на рост кресс-салата

\begin{tabular}{|l|c|c|c|c|c|}
\hline $\begin{array}{c}\text { Серия } \\
\begin{array}{c}\text { вегетационного } \\
\text { опыта }\end{array}\end{array}$ & $\begin{array}{c}\text { Всхожесть } \\
\text { на 5-й } \\
\text { день, \% }\end{array}$ & $\begin{array}{c}\text { Средняя } \\
\text { длина } \\
\text { растений, см }\end{array}$ & $\begin{array}{c}\text { Увеличение } \\
\text { длины растений } \\
\text { относительно } \\
\text { контроля, \% }\end{array}$ & $\begin{array}{c}\text { Сухая } \\
\text { фитомасса } \\
\text { растений, } \\
\text { г/сосуд }\end{array}$ & $\begin{array}{c}\text { Увеличение } \\
\text { сухй фитомассы } \\
\text { растений } \\
\text { относительно } \\
\text { контроля, \% }\end{array}$ \\
\hline Контроль & 73 & 6,6 & 0 & 0,09 & 0 \\
\hline Мочевина & 82 & 4,9 & -26 & 0,08 & -11 \\
\hline $\begin{array}{l}\text { Подложка } \\
\text { из коры }\end{array}$ & 100 & 8,0 & 21 & 0,16 & 78 \\
\hline $\begin{array}{l}\text { Удобрение } \\
\text { из коры }\end{array}$ & 87 & 7,0 & 6 & 0,17 & -11 \\
\hline $\begin{array}{l}\text { Подложка } \\
\text { из луба }\end{array}$ & 87 & 7,1 & 8 & 0,08 & 44 \\
\hline $\begin{array}{l}\text { Удобрение } \\
\text { из луба }\end{array}$ & & & & 0,13 & \\
\hline
\end{tabular}

При повторном посеве семян кресс-салата в почву с органическими удобрениями на основе подложек из коры и луба березы по всем изучаемым параметрам были получены лучшие результаты по сравнению с контрольными опытами (табл. 5). Эффективность этих удобрений при повторном посеве свидетельствует об их пролонгирующем действии.

В работе [48] показана возможность получения калийных биокомпозитных удобрений пролонгированного действия пропиткой пористых подложек из луба и коры березы водным раствором хлорида калия. Исследования показали, что повышение температуры сушки пропитанных подложек от 40 до $105^{\circ} \mathrm{C}$ приводит к уменьшению количества соли, локализованной на их внешней поверхности. Это способствует уменьшению (на 17 \%) вымывания хлорида калия водой из удобрения. Установлено, что биокомпозитные удобрения обладают способностью к медленному вымыванию $\mathrm{KCl}$ в течение длительного времени и через 96 ч вымывания водой в удобрениях остается не менее 17,8 \% калия (табл. 6). 
Таблица 5. Влияние азотсодержащих удобрений и подложек из коры и луба березы на рост кресс-салата при повторной посадке в ту же почву

\begin{tabular}{|l|c|c|c|c|c|}
\hline $\begin{array}{c}\text { Серия } \\
\text { вегетационного } \\
\text { опыта }\end{array}$ & $\begin{array}{c}\text { Всхожесть } \\
\text { на 5-й } \\
\text { день, \% }\end{array}$ & $\begin{array}{c}\text { Средняя } \\
\text { длина } \\
\text { растений, см }\end{array}$ & $\begin{array}{c}\text { Увеличение } \\
\text { длины растений } \\
\text { относительно } \\
\text { контроля, \% }\end{array}$ & $\begin{array}{c}\text { Сухая } \\
\text { фитомасса } \\
\text { растений, } \\
\text { г/сосуд }\end{array}$ & $\begin{array}{c}\text { увеличение } \\
\text { растений } \\
\text { относительно } \\
\text { контроля, \% }\end{array}$ \\
\hline Контроль & 78 & 6,2 & 0 & 0,08 & 0 \\
\hline Мочевина & 70 & 6,1 & -2 & 0,10 & 25 \\
\hline $\begin{array}{l}\text { Подложка } \\
\text { из коры }\end{array}$ & 87 & 7,9 & 27 & 0,15 & 100 \\
\hline $\begin{array}{l}\text { Удобрение } \\
\text { из коры }\end{array}$ & 88 & 7,9 & 27 & 0,16 & 50 \\
\hline $\begin{array}{l}\text { Подложка } \\
\text { из луба }\end{array}$ & 87 & 8,0 & 29 & 0,12 & 88 \\
\hline $\begin{array}{l}\text { Удобрение } \\
\text { из луба }\end{array}$ & 7,0 & & & \\
\hline
\end{tabular}

Таблица 6. Вымывание $\mathrm{KCl}$ из биокомпозитных удобрений (БУ) на основе луба и коры березы, высушенных при $105^{\circ} \mathrm{C}$

\begin{tabular}{|c|c|c|c|c|}
\hline \multirow{2}{*}{$\begin{array}{c}\text { Материал } \\
\text { подложки БУ }\end{array}$} & $\begin{array}{c}\text { Исходное } \\
\text { содержание калия, } \\
\text { мас. \% }\end{array}$ & \multicolumn{2}{|c|}{$\begin{array}{c}\text { Остаточное содержание } \mathrm{KCl} \\
\text { после вымывания водой, мас. \%* }\end{array}$} \\
\cline { 2 - 5 } & 1,0 & 24 ч & 48 ч & 96 ч \\
\hline \multirow{3}{*}{ Луба коры березы } & 2,5 & $19,1 \pm 0,1$ & $18,7 \pm 0,1$ & $17,8 \pm 0,1$ \\
& 5,0 & $24,1 \pm 0,2$ & $23,6 \pm 0,1$ & $22,7 \pm 0,1$ \\
& 7,5 & $27,9 \pm 0,2$ & $27,3 \pm 0,2$ & $26,4 \pm 0,1$ \\
& 1,0 & $28,1 \pm 0,3$ & $27,5 \pm 0,2$ & $26,6 \pm 0,2$ \\
\hline \multirow{2}{*}{ Коры березы } & 2,5 & $22,6 \pm 0,1$ & $22,1 \pm 0,1$ & $21,2 \pm 0,1$ \\
& 5,0 & $27,9 \pm 0,2$ & $27,4 \pm 0,1$ & $26,5 \pm 0,2$ \\
& 7,5 & $32,7 \pm 0,2$ & $32,1 \pm 0,2$ & $31,2 \pm 0,2$ \\
\hline
\end{tabular}

* От исходного содержания калия.

Средняя скорость выделения соли водой, определенная по данным табл. 6, мало зависит от природы подложки и количества нанесенного калия и составляет $0.43-0.50$ мас. \% в сутки. Наибольшей водостойкостью характеризуются удобрения, содержащие 5,0-7,5 мас. \% калия. Период полного вымывания соли из удобрений, рассчитанный на основании экспериментальных данных, составляет не менее 55 сут, что обеспечивает эффект их пролонгирующего действия.

Важно отметить, что достаточно большое выделение $\mathrm{KCl}$ водой в первые 5-30 мин (до $63 \%$, установленное в работе [48], нельзя считать недостатком предлагаемых биокомпозитных удобрений. Такой характер выделения необходим для эффективного устранения дефицита калия в почве, с этой целью и применяются водорастворимые минеральные удобрения. 
Таблица 7. Вымывание фосфатов из биокомпозитных удобрений (БУ) на основе луба и коры березы

\begin{tabular}{|l|c|c|c|c|c|}
\hline \multirow{2}{*}{$\begin{array}{c}\text { Материал } \\
\text { подложки БУ }\end{array}$} & $\begin{array}{c}\text { Исходное } \\
\text { содержание } \\
\text { фосфора, мас. \% }\end{array}$ & 10 мин & 1 ч & 24 ч & 72 ч \\
\cline { 3 - 6 } & 3,5 & $18,3 \pm 0,3$ & $24,7 \pm 0,5$ & $29,5 \pm 0,7$ & $33,2 \pm 1,1$ \\
Луба коры & 4,0 & $18,5 \pm 0,3$ & $25,1 \pm 0,5$ & $29,8 \pm 0,7$ & $34,1 \pm 1,1$ \\
березы & 4,5 & $22,6 \pm 0,4$ & $28,6 \pm 0,8$ & $33,2 \pm 1,1$ & $36,3 \pm 1,2$ \\
& 5,0 & $27,9 \pm 0,5$ & $31,8 \pm 1,1$ & $39,7 \pm 1,0$ & $44,9 \pm 1,2$ \\
\hline Коры березы & 3,5 & $23,7 \pm 0,4$ & $26,2 \pm 0,5$ & $31,4 \pm 1,2$ & $34,1 \pm 1,2$ \\
& 4,0 & $24,2 \pm 0,4$ & $26,9 \pm 0,5$ & $31,8 \pm 1,2$ & $34,5 \pm 1,2$ \\
& 4,5 & $27,5 \pm 0,5$ & $31,3 \pm 1,2$ & $33,6 \pm 1,1$ & $37,5 \pm 1,2$ \\
& 5,0 & $32,7 \pm 0,5$ & $34,2 \pm 1,2$ & $40,3 \pm 1,5$ & $45,6 \pm 1,3$ \\
\hline Суперфосфат простой (3АО КАЗ & & & & $82,6 \pm 2,1$ \\
\hline
\end{tabular}

* от исходного содержания фосфора.** образец сравнения.

В работе [49] показана возможность получения фосфорных биокомпозитных удобрений, обладающих повышенной устойчивостью к вымыванию водой активных компонентов, путем пропитки пористых подложек из луба и коры березы водным раствором $\mathrm{K}_{2} \mathrm{HPO}_{4}$. Авторами предложена последовательность операций (изотермическая выдержка, сушка и обработка кислотой), позволяющих существенно снизить вымывание фосфатов водой из получаемых удобрений (рис. 1). Определены условия получения биокомпозитных удобрений с наибольшей устойчивостью к вымыванию фосфатов: изотермическая выдержка пропитанных образцов при $100{ }^{\circ} \mathrm{C}$ в течение 2 ч; сушка при $200{ }^{\circ} \mathrm{C}$ и последующая обработка $0,1 \mathrm{~N}$ раствором $\mathrm{HNO}_{3}$. Полученные в этих условиях биокомпозитные удобрения обладают способностью к медленному вымыванию фосфатов в течение длительного времени, что определяет эффект их пролонгированного действия (табл. 7).

Наибольшей устойчивостью к вымыванию фосфатов обладают образцы удобрений, содержащие 3,5-4,0 мас. \% фосфора. По своей водостойкости биокомпозитные удобрения на основе подложек из коры и луба березы превосходят промышленное гранулированное удобрение с торговым названием «Суперфосфат простой» (ЗАО КАЗ «Вика», Кемерово). Важно отметить, что данные биокомпозитные удобрения характеризуются хорошей устойчивостью к вымыванию калия водой. Так, в течение 24 ч в воду переходит 25 и 46 \% калия из образцов удобрений на основе подложек из луба и коры березы соответственно. Это существенно меньше по сравнению с вымыванием активного компонента в виде хлорида калия [48].

Результаты исследований, приведенных в работах [47-49], показывают, что отходы коры березы как сырье для получения пористых носителей в удобрениях с пролонгированным действием способны конкурировать с традиционно используемыми в этих целях природными цеолитами.

\section{Заключение}

Обзор литературы, опубликованной в последние 10-12 лет, выявил высокий уровень научной и патентной активности в области получения органоминеральных удобрений из отходов 
древесной коры. По-прежнему остаются актуальными биотехнологические методы получения удобрений на основе коры в присутствии различных добавок, особенно компостирование. Следует отметить значимость разработок, предлагающих перерабатывать совместно с корой отходы других производств, что позволяет использовать ресурс их биогенных компонентов. Проведенный обзор показал, что основным недостатком биотехнологических подходов остается большая продолжительность процесса получения удобрений из коры. Поэтому разработка способов, исключающих биопереработку древесного сырья, имеет большое практическое значение.

Показано, что применение гранулирования древесной коры в присутствии различных добавок или ее обработки методом окислительного аммонолиза позволяет существенно сократить продолжительность процесса получения органоминеральных удобрений. В литературе, опубликованной по исследуемой тематике, изложена возможность получения нового перспективного вида удобрения на основе березовой коры - биокомпозитных удобрений пролонгированного действия. Впервые предложено для нанесения биогенных элементов питания растений применять пористые подложки из коры и луба березы, получаемые обработкой сырья водным раствором щелочи. В результате такой обработки происходит удаление фитотоксичных полифенольных веществ и развитие структуры подложек. Разработанные способы дают возможность получать биокомпозитные удобрения, характеризующиеся способностью к медленному вымыванию водой нанесенных активных элементов (азота, калия и фосфатов) в течение длительного времени. Пролонгированное выделение этих питательных элементов обеспечивает большую эффективность предлагаемых биокомпозитов по сравнению с традиционными водорастворимыми удобрениями. Подложки из древесной коры являются более перспективным материалом по сравнению с предлагаемыми в этих целях природными минералами, поскольку в результате их биодеградации почва обогащается комплексом органических веществ.

Привлечение отходов коры для получения удобрений пролонгированного действия позволяет не только рационально использовать ресурсный потенциал древесных отходов, но и сделать такие удобрения более доступными.

\section{Список литературы}

1. Житков А.В. Утилизация древесной коры. М.: Лесн. пром-сть, 1985. 136 c. [Zhitkov A.V. Utilization of wood bark. M.: Lesn. prom-st, 1985. 136 p. (in Puss.)]

2. John M. Harkim, John W. Rowe Bark and its possible uses. Madison: U.S. Department of Agriculture. WIS. FPL-091: 1971. 56 p.

3. Гелес И.С. Древесное сырье - стратегическая основа и резерв цивилизации. Петрозаводск: Карельский научный центр РАН, 2007. 499 c. [Geles I.S. Drevesnoe syr’e - strategicheskaya osnova i rezerv civilizacii. Petrozavodsk: Karel'skij nauchnyj centr RAN, 2007. 499 p. (in Russ.)]

4. Черников В.А., Алексахин Р.М., Голубев А.В. Агроэкология / под ред. В.А. Черникова, А.И. Чекереса. М.: Колос, 2000. 536 с. [Chernikov V.A., Aleksaxin R.M.,Golubev A.V. Agroekologiya / pod red. V.A. Chernikova. A.I. Cherkesa. M.: Kolos, 2000.536 p. (in Russ.)]

5. Егорова Р.А., Ревенский В.А., Влияние компостов на содержание и запасы органического вещества в почве. Плодородие 2013. T. 74 (5), C. 17-18. [Egorova R.A., Revensky V.A. Effect

$$
-425-
$$


of compost on the component and reserves of organic matter un the soil. Plodorodie 2013. T. 74 (5), P. 17-18. (in Russ.)]

6. Варфоломеев Л.А Приготовление промышленных компостов на основе твердых отходов деревообработки. М.: Наука, 1992. 52 с. [Varfolomeev L.A. Prigotovlenie promyshlennyх kompostov na osnove tvyordyx otxodov derevoobrabotki. M.: Nauka, 1992. 52 p. (in Russ.)]

7. Гаврилов Т.А., Паталайнен Л.С., Колесников Г.Н., О ресурсосберегающих технологиях экологически безопасной утилизации древесной коры. Современные научные исследования и инновации 2014. T. 39(7), C. 59-64. [Gavrilov T.A., Patalaynen L.S., Kolesnikov G.N. About resourcesaving technology and of ecologically safe utilization of tree bark. Contemporary science investigation and innovation. 2014. T. 39 (7), P. 59-64. (in Russ.)]

8. Компостирование твердых органических отходов производства и потребления. Вермикомпостирование: монография /Под. ред. Я.И. Вайсмана. Пермь: Изд-во Перм. гос. техн. ун-та, 2010. 557 с. [Kompostirovanie tvyordyx organicheskix otxodov proizvodstva. i potrebleniya. Vtrmikompostirovanie: monografiya / pod red. Ya. I. Vajsmana. Perm: Izd-vo Perm. Gos. Texn. Un-ta, 2010. 557 p. (in Russ.)]

9. Корсунова Ц.Д., Чимитдоржиева Г.Д. Биологическая активность дефлированных каштановых почв Байкальского региона при внесении компостов на основе древесной коры, опилок, соломы. Агрохимия. 2008. № 4, C. 15-19. [ Korsunova C.D.C., Chimitdorzhieva G.D. Biologicheskaya aktivnost deflirovannyx kashtanovyx pochv Baikal'skogo regiona pri vnesenii kompostov na osnove drevesnoj kopy, opilok. Solomy. Agrucaltural Chemistry. 2008. № 4. P. 15-19. (in Russ.)]

10. Ульянова О.А. Трансформация органического вещества почвы под действием композиций из древесной коры и цеолита. Плодородие 2009. № 2, С. 23-25. [Ulyanova O.A. Transformation of organic matter unde compaunds from wood bark and zeolite. Plodorodie 2009. № 2, P. 23-25. (in Russ.)]

11. Кураченко Н.Л., Ульянова О.А., Чупрова В.В. Влияние систем удобрений на изменение агрофизических свойств темно-серой лесной почвы. Агрохимия 2011. №. 4, С. 22-29. [Kurachenko N.L., Ulyanova O.A., Chuprova V.V. Effect of fertilizing systems on the agrophysical properties of dark grey forest soil. Agrucaltural Chemistry 2011. №. 4, P. 22-29. (in Russ.)]

12. Белюченко И.С., Антоненко Д.А. Влияние сложного компоста на агрегатный состав и водно-воздушные свойства чернозема обыкновенного. Почвоведение 2015. № 7, С. 858-864. [Belyuchenko I.S., Antonenko D.A. The influence of complex compost on the aggregate composition and water and air properties of an ordinary chernozem. Soil science 2015. № 7, P. 858-864. (in Russ.)]

13. Alan L. Wright, Tony L. Provin, Frank M.Hons, David A. Zuberer, Richard H. White Nutrient accumulation and availability in compost - amended turfgrass soil. Journal of Hortscience 2007. Vol. 42. October, P. 1473-1477.

14. Green J., Harp D.A., Ong K.L. Comparison of Phytophtore disease incidence in composted pine bark mixes to chemical and biological controls. Journals of Hortscience 2012. Vol. 47. October, P. 1499-1503.

15. Патент РФ 2283294. Ульянова О.А., Люкшина И.В., Чупрова В.В., Кулебакин В. Состав для производства органоминерального удобрения. Опубл. 10.09.2009, БИ 25. [Patent RU 
2283294. Ulyanova O.A., Lyukshina I.V., Chuprova V.V., Kulebakin V. Sostav dlya proizvodstva organjmineral'nogo udobreniya. Publ Date 10.09.2009. BI 25. (in Russ.)]

16. Патент РФ 2496752. Червонобаб Н.Л. Способ получения органоминерального удобрения пролонгированного действия (Варианты). Опубл. 27.10.2013. БИ 30. [Patent RU 2496752. Chtrvonobab N.L. Sposob polucheniya organjmineral'nogo udobreniya prolongirovannogo dejstviya. Publ. Date 27.10.2013. BI 30. (in Russ.)]

17. Patent KR 20100080574. Suh Hee Dong. Bulking agent for organic composting. Date publ. 09.07.2010.

18. Пахненко Е.П. Осадки сточных вод и другие нетрадиционные органические удобрения [Электронный ресурс]: 2-е изд. М.: БИНОМ. Лаборатория знаний, 2012. 311 с. [Paxnenko E.P. Osadki stochbyx vod I drugie netradicionnye organicheskie udobreniya [Elektronnyj resurs]: 2-e izd. M.: BINOM. Laboratoriya znanij, 2012. 311 p. (in Russ.)]

19. Патент РФ 2520022. Горелов В.В., Иларионов С.А., Басов В.Н., Кузовкина В.А., Басов А.В., Зонова Л.Д. Способ переработки короотвала и технологическая площадка для его осуществления. Опубл. 20. 06. 2014. БИ 17. [Petent RU 2520022. Gorelov V.V., Ilarionov S.A., Basov V.N., Kuzovkina V.A., Basov A.V., Zonova L.D. Sposob pererabotki korootvala I texnologicheskaya ploshhadka dlya ego osushhestvleniya. Publ. Date 20.06.2014. BI 17. (in Russ.)]

20. Patent KR 100924071. Shin Hong Sup, Yoo Jee Houn, Yang Dong Min, Park Tae In, Kim Jong Won. Composition of the composted fertilizing the Dam's float wood and sewage sludge and the manufacturing method. Date publ. 27.10.2009.

21. Hachicha S., Cegarra J., Sellami F., Hachicha R., Drira N., Medhioub K., Ammar E. Elimination of polyphenols toxicity from olive mill waste water sludge by co-composting with Sesame Bark. Journal of Hazardous materials 2009. V. 161(1-2), P. 1131-1139.

22. Patent RO 129229. Nedeff V., Ciobanu D., Macoveanu M., Chiriac A., Rusu L., Simon A. Ecological aerobic process for the biodegradation of the mixture formed by the use of excess byproducts from the wood working industry and beer working industry, and the resulting products: ecological organic biofertilizers. Date publ. 28.02.2014.

23. Patent RO 129756. Lungu M.-L., Memet E., Carapcea A.-C. Organic fertilizer made of wood industry, beer and dairy industry by-products. Date publ. 30.09.2014.

24. Patent UA 33661. Bunchak O.M., Hnydiuk V.S., Kolisnyk N.M., Melnik I.P. Method for production of organic fertilizer of universal action from waste of leather production. Date publ. 10.07.2008.

25. Патент РФ 2337085. Тертычный В.П.Способ получения органического удобрения из отходов деревооработки хвойных пород. Опубл. 27.10.2008. БИ 30. [Patent RU 2337085. Tertychnyj V.P. Sposob polucheniya organicheskogo udobreniya iz otxodov derevoobrabotki xvoinyx porod. Publ. Date 27.10.2008. BI 30 (in Russ.)]

26. Ginnis M.S., Bilderback T.E., Warren S.L. Vermicompost amended pine bark provides most plant nutrients for Hibiscus moscheutos «Luna Blush». Acta Horticultural 2011. Vol. 891, P. 249-256.

27. Кузнецов Б.Н., Рязанова Т.В., Щипко М.Л., Кузнецова С.А., Веприкова Е.В., Чупрова Н.А. Оптимизация термических и биохимических методов утилизации отходов экстракционной переработки березовой коры. Химия в интересах устойчивого развития 2005. Т. 13(3), С. 441-449. [Kuznetsov B.N., Ryazanova T.V., Schipko M.L., Kuznetsova S.A., Veprikova E.V., Chuprova 
N.A. Optimization of thermal and biochemical methods of utilization of wasters of birch bark extraction treatment. Chemistry for sustainable development 2005. T. 13(3), P. 441-449. (in Russ.) ]

28. Ульянова О.А., Нечаева А.С., Хижняк С.В. Трансформация сосновой коры и композиций на ее основе. Вестник Красноярского государственного аграрного университета 2009. № 11, C. 126-130. [Ulyanova O.A., Nechaeva A.S., Khishnyak S.V. Transformation of pine bark and compositions on its basis. Herald of KrasGAU 2009. № 11, P. 126-130. (in Russ.) ]

29. Нечаева А.С., Ульянова О.А. Трансформация лиственничной коры и композиций на ее основе. Вестник Красноярского государственного аграрного университета 2010. № 4, С. 19-24. [Nechaeva A.S., Ulyanova O.A. Transformation of larch bark and compositions on its basis. Herald of KrasGAU 2010. № 4, P.19-24. (in Russ.)]

30. Ульянова О.А., Чупрова В.В. Минерализация коры разных видов деревьев и удобрительных композиций на ее основе. Агрохимия 2015. № 2, С. 33-45. [Ulyanova O.A., Chuprova V.V. Mineralization of bark from different tree species and bark-based fertilizers compositions. Agrucaltural Chemistry 2015. № 2, P. 33-45. (in Russ.)]

31. Ульянова О.А., Чупрова В.В. Гумификация коры различных видов деревьев и удобрительных композиций на ее основе. Агрохимия 2016. № 5, C. 11-20. [Ulyanova O.A., Chuprova V.V. The humification of bark of different species of trees and fertilizer composition on their basis. Agrucaltural Chemistry 2016. № 5, P. 11-20. (in Russ.)]

32. Patent DE 102006019939. Goettlein A., Weis W., Huber C. Fertilizers and process for its preparation Date publ. 19.08.2010.

33. Patent CN 104193527. Qu Tiangui Selenium rich organic fertilizer. Date publ. 10.12.2014.

34. Беловежец Л.А., Волчатова И.В., Медведева С.А. Перспективные способы переработки вторичного лигноцеллюлозного сырья. Химия растительного сырья 2010. № 2, С. 5-16. [Belovejest L,A., Volchatova I.V., Medvedeva S.A. The promising methods of recoverable lignocellulosic materials processing. Chemistry of plant raw materials 2010. N 2, P. 5-16. (in Russ.)]

35. Cristina Trois, Frederic Coulon, Cecile P. de Combret, Jean M.T., Martins Laurent Oxarango Effect of pine bark and compost on the biological denitrification process of non-hazardous landfill leachate: Focus on the microbiology. Journal of Hazardous materials 2010. V. 181(1-3), P. 1163-1169.

36. Krewer G., Ruter J. Fertilizing Highbush Blueberries in pine bark beds. Learning for life. Reviewed March 2009. Bulletin 1291. P. 1-7.

37. Патент РФ 24000357. Григорюк Т.П., Сластников И.И., Старостина Е.Б., Продаевич В.Г., Левав Д.В. Способ переработки коры деревьев хвойных пород. Опубл. 27.09.2010, БИ 27. [Patent RU 24000357. Grigoryuk T.P., Slastnikov I.I.,Starostina E.B., Prodaevich V.G., Levav D.V. Sposob pererabotki kory derev/ev xvojnyx porod. Publ. Date 27.09.2010. BI 27. (in Russ.)]

38. Бадогина А.И., Третьяков С.И., Кутакова Н.А., Коптелова Е.Н. Извлечение биологически активных веществ из луба березовой коры, Химия растительного сырья 2015. № 2, С. 135 140. [Badogina A.I., Tret'yakov S.I., Kutakova N.A., Koptelova E.N. Extraction of biological activity substances from inner birch bark. Chemistry of plant raw materials 2015. № 2, P. 135-140. (in Russ.)]

39. Дейнеко И.П., Нгует Н.Т.М., Дейнеко И.В., Корнилова Л.И. Изучение окислительного аммонолиза сосновой коры. Химия растительного сырья 2007. № 2, С. 13-19. [Dejneko I.P., Hguen N.T.M., Dejneko I.V., Kornilova L.I. Investigation of oxidative ammonolysis of pine bark. Chemistry of plant raw materials 2007. № 2, P. 13-19. (in Russ.)] 
40. Trenkel M.E. Slow- and Controlled - release and stabilized Fertilizers: An option for Enhancing Nutrient Use Efficiency in Agriculture. Second edition. Paris: IFA, 2010. $160 \mathrm{p}$

41. Патент РФ 2502713. Кожевникова Н.М. Торфоцеолитовое удобрение пролонгированного действия, модифицированное фосфатом калия. Опубл. 27.12.2013. [ Patent RU 2502713. Kojevnikova N.M. The peat -zeolite fertilizer of long - time action modified by potassium phosphate. Publ. Date 27.12.2013 (in Russ.)]

42. Патент РФ 2512165. Сержантов В.Г. Минерально-органическое комплексное гранулированное удобрение и способ его получения. Опубл. 10.04.2014. БИ 10. [Serzhantov V.G. Mintral'no-organicheskoe kompleksnoe granulirovannoe udobrenie i sposob ego polucheniya. Hubl. Date 10.04.2014. BI 10 (in Russ.)]

43. Jackson B.E., Wright R.D. Changes in chemical and physical properties of pine tree substrate and pine bark during long-term nursery crop production. Journals of Hortscience 2009. Vol. 44.June, P. 791-799.

44. Jackson B.E., Wright R.D., Alley M.M. Comparison of fertilizer nitrogen avability, nitrogen immobilization, substrate carbon dioxide efflux, and nutrient leaching in peat-lite, pine bark, and pine tree substrates. Journals of Hortscience 2009. Vol. 44.June, P. 781-790.

45. Buamscha G.M., Altland J.E., Sullivan D.M., Horneck D.A. Micronutrient avability in fresh and aged Douglas Fir bark. Journals of Hortscience 2007. Vol. 42. April, P. 152-156.

46. Trois Cr., Pisano G., Oxarango M.L Alternative solutions for the bio-denitrification of landfill leachates using pine bark and compost. Journal of Hazardous Materials 2010. V. 178(1-3), P. 11001105 .

47. Кузнецова С.А., Кузнецов Б.Н., Скурыдина Е.С., Максимов Н.Г., Калачева Г.С., Ульянова О.А., Скворцова Г.П. Синтез и свойства биокомпозитных удобрений на основе мочевины и коры березы. Журнал Сибирского федерального университета. Химия 2013. Т. 6 (4), С. 380-393. [Kuznetsova S.A., Kuznetsov B.N., Skurydina E.S., Maksimov N.G., Kalachova G.S, Ulyanova O.A., Skvortsova C.P. Synthesis and properties of biocomposite fertilizers on the basis of urea and birch bark. Journal of Siberian Federal University. Chemistry 2013. V. 6 (4), P. 380-393. (in Russ.)]

48. Веприкова Е.В., Кузнецова С.А., Чесноков Н.В., Кузнецов Б.Н. Изучение вымывания $\mathrm{KCl}$ водой из биокомпозитных удобрений на основе коры березы Журнал Сибирского федерального университета. Химия 2015. Т. 8 (1). C. 25-34. [Veprikova E.V., Kuznetsova S.A., Chesnokov N.V., Kuznetsov B.N. Study of KCl Leaching by water from Biocomposite Fertilizers Based on Birch Bark. Journal of Siberian Federal University. Chemistry 2015. V. 8 (1), P. 25-34. (in Russ.)

49. Веприкова Е.В., Кузнецова С.А., Чесноков Н.В., Кузнецов Б.Н. Получение и свойства фосфорных биокомпозитных удобрений на основе коры березы. Журнал Сибирского федерального университета. Химия 2015. T. 8 (3), C. 413-421. [Veprikova E.V., Kuznetsova S.A., Chesnokov N.V., Kuznetsov B.N. Preparation and properties of phosphorus boicomposite fertilizers based on the birch bark. Journal of Siberian Federal University. Chemistry 2015. T. 8 (3), P. 413-421. (in Russ.)

50. Веприкова Е.В., Кузнецова С.А., Скворцова Г.П., Щипко М.Л. Свойства и применение сорбционных материалов из луба коры березы Журнал Сибирского федерального университета. Химия 2008. T. 1 (3). C. 286-292. Veprikova E.V., Kuznetsova S.A, Skvortsova C.P., Schipko M.L. properties and Application of the Sorption Materials from Outer Birch-Bark. Journal of Siberian Federal University. Chemistry 2008. V. 1 (3), P. 286-292. (in Russ.)

$$
-429-
$$

